\title{
Impact of COVID-19 on Corporate Liabilities in the Energy \& Power Industry
}

\author{
Hao Xiong ${ }^{1}$, Wen $\mathrm{Shi}^{2}$, Shilin Xu', Huayu Shen ${ }^{3}$ \\ ${ }^{1}$ Guizhou University of Finance and Economics, China, ${ }^{2}$ Beijing Wuzi University, China, ${ }^{3}$ North China Electric Power University, China \\ Keywords: energy and power, liability, debt ratio, covid-19 \\ https://doi.org/10.46557/001c.18936
}

\section{Energy RESEARCH LETTERS}

Vol. 2, Issue 1, 2021

The international industrial chain has been impacted by the COVID-19 pandemic with the energy and power industrial chain most impacted. This paper studies the impact of COVID-19 on energy and power firm liabilities and finds that COVID-19 has (a) raised liabilities of companies, and (b) disrupted production thus reducing performance and raising financial stress.

\section{Introduction}

The political, economic and social impacts of COVID-19 have attracted significant academic interest (Phan \& Narayan, 2020). This paper studies the impact of COVID-19 on firm liabilities in the energy and power industry chain by using a difference-in-difference (DID) model. Our findings confirm that the COVID-19 pandemic is associated with rising debt. We show that firm liabilities for poorly performing firms also significantly increased during the COVID-19 crisis.

Our contributions are as follows: First, contrary to the evolving literature (see Qin et al., 2020; Salisu \& Adediran, 2020; Sharif et al., 2020; Shen et al., 2020; Topcu \& Gulal, 2020), we turn attention on a different aspect of COVID-19 research: that is, we study the impact of COVID-19 on firm liabilities. None of the studies evaluate the effect on liabilities, which is surprising given that the lack of economic activities has led to business losses and hence have put firms into financial stress. Therefore, it is natural to expect that COVID-19 may have also influenced firm liabilities-to what extent, though, is unknown.

We focus on energy and power industry firms' liabilities. Our focus on the energy sector connects to the literature on COVID-19 and energy, where researchers have focused on different aspects of the energy industry. Polemis \& Soursou (2020) show that stock returns of the Greek energy companies are affected by COVID-19; Salisu \& Adediran (2020) show that COVID-19 has contributed to energy market volatility; and Fu \& Shen (2020) demonstrate that due to COVID-19 energy companies have performed poorly.

\section{Theoretical analysis and hypothesis}

Recent years have seen growth of and investments in new energy- related industries. Importantly, innovation in the energy and power industry chain has also grown, and firm liabilities have risen to meet the growth in investments, including potentially excessive investments in oil, nature gas, and human resources (He et al., 2019). Compared with other industries, the debt financing scale of companies in the en- ergy and electric power chain is larger because of its need for infrastructure. However, the sudden COVID-19 outbreak hampered normal operations, with withdrawal of investments, and the burden of high fixed expenses (Chang et al., 2020). Given this situation, firm profitability suffered in the COVID-19 crisis (Shen et al., 2020). Profitable companies overcame funding pressures (Shen et al., 2018).

With energy firms, poor performance implies less access to internal sources of funds. These firms have had to depend on external financing to meet fixed expenditures ( $\mathrm{Fu} \&$ Shen, 2020). Another feature of the debt market has been the role of the stock market volatility which increased due to COVID-19 (Ali et al., 2020) and disrupted innovation-related investment (Shen et al., 2021). Given that the availability and cost of debt financing is lower than equity financing, corporate liabilities have increased during the COVID-19 pandemic. Therefore, we hypothesize that the COVID-19 pandemic caused firm liabilities to increase in the energy and electric power industry.

\section{Model and data}

In this paper, we take the first quarter financial data of Chinese listed companies in Energy and Power industry chain from 2015 to 2020 . We exclude the following samples: (1) distressed firms; (2) finance and insurance firms; and (3) firms with missing data. All data are obtained from the CSMAR database, and continuous variables are winsorized at the $1 \%$ and $99 \%$ levels. The following DID model was used to test the main hypothesis:

$$
\begin{aligned}
L E V_{i t}= & \beta_{1} S_{E R I O U} S_{i t} \times P_{E R I O D_{i t}}+\beta_{2} P_{E R I O D_{i t}} \\
& +\beta_{3} \text { SERIOU }_{i t}+\beta_{4} \text { SIZE }_{i t}+\beta_{5} \text { ROE }_{i t} \\
& +\beta_{6} \text { GROWT }_{i t}+\beta_{7} \text { FIX }_{i t}+\beta_{8} C A S H_{i t} \\
& +\beta_{9} \text { MB }_{i t}+\beta_{10} L A R G E_{i t}+\beta_{11} I N D_{i t} \\
& +\beta_{12} Y E A R_{i t}+\varepsilon_{i t}
\end{aligned}
$$

In this model, the asset-liability ratio $(L E V)$ is the dependent variable, which is measured by the ratio of liabilities to total assets and reflects the level of firm liabilities. PERIOD is a dummy variable to signify the period of the COVID-19 outbreak: it takes a value 1 in the first quarter of 2020 and 0 otherwise. SERIOUS is a dummy variable of the "degree 
Table 1: Descriptive analysis

\begin{tabular}{lccccc}
\hline Variables & $\mathrm{N}$ & Mean & Sd & Min & Max \\
\hline LEV & 2082 & 0.461 & 0.189 & 0.0540 & 0.877 \\
SIZE & 2082 & 22.60 & 1.239 & 20.10 & 26.43 \\
ROE & 2082 & 0.058 & 0.100 & -0.415 & 0.362 \\
GROWTH & 2082 & -0.264 & 0.303 & -0.886 & 1.242 \\
FIXS & 2082 & 0.241 & 0.173 & 0.002 & 0.713 \\
CASH & 2082 & 0.111 & 0.085 & 0.010 & 0.531 \\
MB & 2082 & 0.632 & 0.242 & 0.112 & 1.167 \\
LARGE & 2082 & 0.320 & 0.148 & 0.086 & 0.730 \\
\hline
\end{tabular}

This table provides selected descriptive statistics of variables in the main regression model, including mean, maximum (Max), minimum (Min) and standard deviation (Sd).

of the pandemic impact" based on return on total assets $(R O A)$. When the annual $R O A$ observation is lower than current $R O A$ 's 75 th percentile values, it takes a value 1 , otherwise we set it to 0 . We also control for the following variables: SIZE (calculated by the logarithm of total assets), $R O E$ (the ratio of net profits to net assets), GROWTH (measured by revenue growth to current operating income), FIXS (the ratio of fixed assets to total assets), $C A S H$ (the ratio of cash-holdings to total assets), $M B$ (book-to-market equity ratio), and $L A R G E$ (share ratio of the largest shareholder). Table 1 describes the descriptive statistical analysis of each variables.

\section{Empirical analysis and results}

\section{A. Unit root test and parallel trend test}

The unit root test shows that all variables have passed the test at the $1 \%$ level, and the integration order of the panel data can be considered stable. The parallel trend test shows that the data from high- and low- impacted companies before the pandemic have the same trend, which can be further studied via the DID modeling. The results are shown in Figure 1.

\section{B. Regression results}

Table 1 shows the empirical results. In Column (1), all companies in the energy and power industry are taken as samples to test the impact of COVID-19 on firm liabilities in the energy and power industrial chain. The interaction coefficient of SERIOUS*PERIOD is 0.0278 and significantly positive at the $5 \%$ level, indicating that the COVID-19 pandemic had a strong impact on corporate liabilities in the energy and power industry. High fixed cost, matured payments on capital and interests cannot be repaid without strong firm performance and sufficient cash flow. Meanwhile, larger scale and higher proportion of fixed assets can lead to growing debt, and compared to companies with lower profitability, slower revenue growth, and higher cashholdings, strong financial strength relieves the pressure on corporate debt.

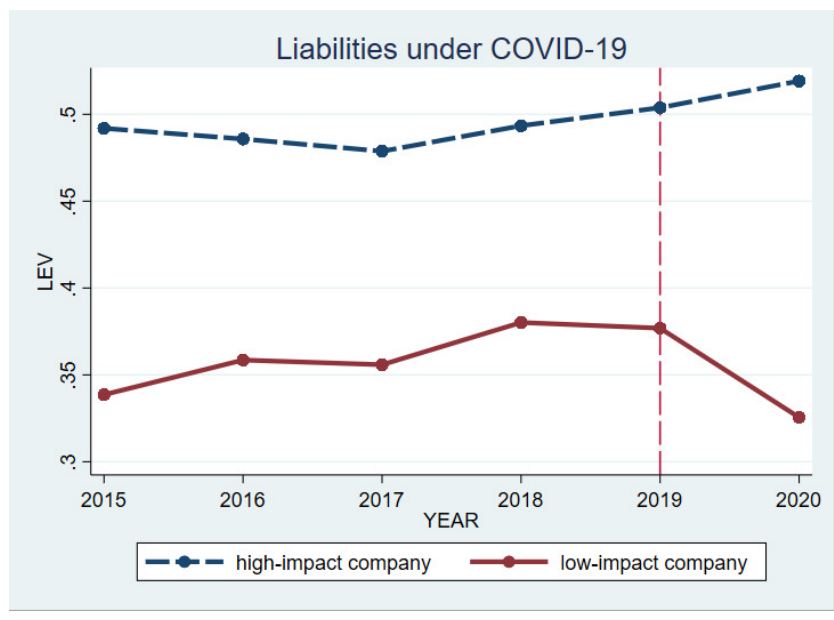

Figure 1: Parallel trend test

This figure depicts parallel trend test based on the financial data of China's listed energy companies from 2015 to 2020 .

\section{Robustness test}

In robustness tests, we apply an alternative dependent variable, a propensity score matching approach, and reset samples to evaluate the reliability and stability of the main empirical results. Firstly, the ratio of liabilities to revenue was treated as an alternative dependent variable. The $S E$ RIOUS ${ }^{*} P E R I O U D$ coefficient is 1.7191 and it is significantly positive at the $1 \%$ level. The results remained consistent (see Column 2, Table 2). Secondly, the companies in the energy and power industry are taken as the experimental group to compare with other industry companies in the DID test, and propensity score matching was used to overcome sample selection bias. The empirical result in column (3) remains robust and the model is as follows with all variables are defined previously in Equation (1):

$$
\begin{aligned}
L E V_{i t}= & \beta_{1} T R E A T_{i t} \times P_{E R I O D_{i t}}+\beta_{2} P_{E R I O D_{i t}} \\
& +\beta_{3} T R E A T_{i t}+\beta_{4} S_{I Z E_{i t}+\beta_{5} R O E_{i t}} \\
& +\beta_{6} G R O W T H_{i t}+\beta_{7} F I X S_{i t}+\beta_{8} C A S H_{i t} \\
& +\beta_{9} M B_{i t}+\beta_{10} L A R G E_{i t}+\beta_{11} I N D_{i t} \\
& +\beta_{12} Y E A R_{i t}+\varepsilon_{i t}
\end{aligned}
$$


Table 2: Empirical results

\begin{tabular}{|c|c|c|c|}
\hline & (1) & (2) & (3) \\
\hline SERIOUS*PERIOD & $\begin{array}{l}0.0278^{* *} \\
(2.4687)\end{array}$ & $\begin{array}{c}1.7191^{* * *} \\
(2.7766)\end{array}$ & \\
\hline SERIOUS & $\begin{array}{c}-0.0038 \\
(-0.6424)\end{array}$ & $\begin{array}{c}0.2027 \\
(0.6189)\end{array}$ & \\
\hline TREAT*PERIOD & & & $\begin{array}{l}0.0122^{*} \\
(1.6895)\end{array}$ \\
\hline TREAT & & & $\begin{array}{c}0.0152 \\
(1.6183)\end{array}$ \\
\hline PERIOD & $\begin{array}{c}-0.0376^{* * *} \\
(-3.1915)\end{array}$ & $\begin{array}{c}-2.9832^{* * *} \\
(-4.6040)\end{array}$ & $\begin{array}{c}-0.0387^{* * *} \\
(-5.2162)\end{array}$ \\
\hline ROE & $\begin{array}{c}-0.1789^{* * *} \\
(-8.0259)\end{array}$ & $\begin{array}{c}-9.7528^{* * *} \\
(-7.9545)\end{array}$ & $\begin{array}{c}-0.2410^{* * *} \\
(-14.7097)\end{array}$ \\
\hline SIZE & $\begin{array}{l}0.0815^{* * *} \\
(11.1931)\end{array}$ & $\begin{array}{c}3.2562^{* * *} \\
(8.1355)\end{array}$ & $\begin{array}{l}0.0782^{* * *} \\
(23.7035)\end{array}$ \\
\hline GROWTH & $\begin{array}{l}-0.0150^{* *} \\
(-1.9899)\end{array}$ & $\begin{array}{l}-4.9430^{* * *} \\
(-11.9430)\end{array}$ & $\begin{array}{l}-0.0142^{* *} \\
(-2.3283)\end{array}$ \\
\hline FIXS & $\begin{array}{l}0.0651^{* *} \\
(2.1778)\end{array}$ & $\begin{array}{c}0.7593 \\
(0.4616)\end{array}$ & $\begin{array}{c}0.0624^{* * *} \\
(3.2809)\end{array}$ \\
\hline $\mathrm{CASH}$ & $\begin{array}{c}-0.2499^{* * *} \\
(-8.4868)\end{array}$ & $\begin{array}{c}-4.0051^{* *} \\
(-2.4729)\end{array}$ & $\begin{array}{c}-0.3005^{* * *} \\
(-12.6503)\end{array}$ \\
\hline MB & $\begin{array}{l}-0.0351^{*} \\
(-1.9171)\end{array}$ & $\begin{array}{c}3.3312^{* * *} \\
(3.3087)\end{array}$ & $\begin{array}{c}-0.0106 \\
(-0.8184)\end{array}$ \\
\hline LARGE & $\begin{array}{c}-0.1180^{* * *} \\
(-2.6282)\end{array}$ & $\begin{array}{c}-5.1251^{* *} \\
(-2.0752)\end{array}$ & $\begin{array}{c}-0.0667^{* * *} \\
(-2.9116)\end{array}$ \\
\hline Constant & $\begin{array}{c}-1.5169^{* * *} \\
(-8.5671)\end{array}$ & $\begin{array}{c}-42.3125^{* *} \\
(-4.3448)\end{array}$ & $\begin{array}{l}-1.2356^{* * *} \\
(-16.3419)\end{array}$ \\
\hline YEAR & Yes & Yes & Yes \\
\hline IND & Yes & Yes & Yes \\
\hline $\operatorname{Adj}-R^{2}$ & 0.1738 & 0.0444 & 0.4539 \\
\hline$N$ & 2082 & 2082 & 3781 \\
\hline
\end{tabular}

This table has regression results on the impact of COVID-19 on energy and power corporate liabilities. Column (1) shows that regression results for the energy and power company sample; column (2) shows the regression results in the alternative dependent variable; and column (3) shows the regression results for the total company after propensity score matching.

\section{Conclusion}

This paper studies firm liabilities in the energy and power industry chain. We find that the liabilities of companies in the energy and power industry chain increased significantly during the COVID-19 pandemic period. On the one hand, the external market environment was more uncertain in the COVID-19 crisis, thus production and consumption in the energy sector were seriously impacted. On the other hand, high fixed expenses, poor performance and tight cash flows led to growing debt and disinvestment in the energy industry.

\section{Acknowledgement}

We acknowledge support from Science and Technology Department of Guizhou Province ([2020]4Y173) in the completion of this project. We would also like to thank the anonymous referee and Editor of Energy RESEARCH LETTERs for their valuable comments in improving this study. 


\section{REFERENCES}

Ali, M., Alam, N., \& Rizvi, S. A. R. (2020). Coronavirus (COVID-19) - An epidemic or pandemic for financial markets. Journal of Behavioral and Experimental Finance, 27, 100341. https://doi.org/10.1016/j.jbef.202 $\underline{0.100341}$

Chang, C.-L., McAleer, M., \& Wong, W.-K. (2020). Risk and Financial Management of COVID-19 in Business, Economics and Finance. Journal of Risk and Financial Management, 13(5), 102. https://doi.org/10.3 390/jrfm13050102

Fu, M., \& Shen, H. (2020). COVID-19 and Corporate Performance in the Energy Industry. Energy Research Letters, 1(1). https://doi.org/10.46557/001c.12967

He, P., Sun, Y., Shen, H., Jian, J., \& Yu, Z. (2019). Does Environmental Tax Affect Energy Efficiency? An Empirical Study of Energy Efficiency in OECD Countries Based on DEA and Logit Model. Sustainability, 11(14), 3792. https://doi.org/10.3390/s u11143792

Phan, D. H. B., \& Narayan, P. K. (2020). Country Responses and the Reaction of the Stock Market to COVID-19-a Preliminary Exposition. Emerging Markets Finance and Trade, 56(10), 2138-2150. http s://doi.org/10.1080/1540496x.2020.1784719

Polemis, M., \& Soursou, S. (2020). Assessing the Impact of the COVID-19 Pandemic on the Greek Energy Firms: An Event Study Analysis. Energy Research Letters, 1(3), 17238. https://doi.org/10.4655 7/001c.17238

Qin, M., Zhang, Y.-C., \& Su, C.-W. (2020). The Essential Role of Pandemics: A Fresh Insight into the Oil Market. Energy Research Letters, 1(1), 13166. http s://doi.org/10.46557/001c.13166
Salisu, A., \& Adediran, I. (2020). Uncertainty due to infectious diseases and energy market volatility. Energy Research Letters, 1(2), 14185. https://doi.org/1 $\underline{0.46557 / 001 \mathrm{c} .14185}$

Sharif, A., Aloui, C., \& Yarovaya, L. (2020). COVID-19 pandemic, oil prices, stock market, geopolitical risk and policy uncertainty nexus in the US economy: Fresh evidence from the wavelet-based approach. International Review of Financial Analysis, 70, 101496. https://doi.org/10.1016/j.irfa.2020.101496

Shen, H., Fu, M., Pan, H., Yu, Z., \& Chen, Y. (2020). The Impact of the COVID-19 Pandemic on Firm Performance. Emerging Markets Finance and Trade, 56(10), 2213-2230. https://doi.org/10.1080/1540496 x.2020.1785863

Shen, H., Xia, N., \& Zhang, J. (2018). Customer-based Concentration and Firm Innovation. Asia-Pacific Journal of Financial Studies, 47(2), 248-279. https://do i.org/10.1111/ajfs.12210

Shen, H., Zheng, S., Xiong, H., Tang, W., Dou, J., \& Silverman, H. (2021). Stock market mispricing and firm innovation based on path analysis. Economic Modelling, 95, 330-343. https://doi.org/10.1016/j.econ mod.2020.03.001

Topcu, M., \& Gulal, O. S. (2020). The impact of COVID-19 on emerging stock markets. Finance Research Letters, 36, 101691. https://doi.org/10.1016/ j.frl.2020.101691 